\title{
ACRL in Los Angeles
}

ACRL Program Meetixg: "The Educational Role of the Academic Library" (June 27, 2:00-4:00 p.m.) will be the theme of the ACRL Program Meeting in Los Angeles. Robert O'Neil, president of the University of $W$ isconsin System, will deliver the keynote address. Following him will be a panel consisting of Warren J. Haas, president of the Council on Library Resources; Richard J. Wood, vice-president for academic affairs, Whittier College; and Joseph A. Boissé, director of libraries at Temple University. The panelists will react to the address from their particular points of view. A business meeting, Carla Stoffle presiding, will be held prior to the program. Julie Carroll Virgo will give the ACRL Executive Director's report.

The ACRL Reception, sponsored by the Baker \& Taylor Company, will follow the Program Meeting from 6:00-8:00 p.m. in the Sierra Room of the Los Angeles Hilton. The reception will provide food and a cash bar. Activities will include the pre sentation of Baker \& Taylor's Academic or Research Librarian of the Year Award.

ANThropology and Sociology Section: "Access Tools for Information in Anthropology' and Sociology: The Publishers Speak" (June 28, 2:00-4:00 p.m.) will attempt to establish better communication with publishers of bibliographic tools in sociology and anthropology and to begin a dialogue concerning the depth and quality of access currently offered by their publications and their goals for the future. Scheduled speakers are: Leo P. Chall, editor, Sociological Abstracts; Eileen Peroneau, documentation editor, Sage Publications; Kenyon C. Rosenberg, associate director for bibliographic and document services, NTIS; Norman Cohen, president, Baywood Publishing Company; Jonathan Benthall, director, Royal Anthropological Institute of Great Britain and Ireland; and Francis X. Grollig, anthropologist, Loyola University. A reactor panel will consist of Chris Ferguson, University of California, Irvine; Gregory A. Finnegan, Roosevelt University, and Sandra S. Kerbel, University of Pittsburgh. The program will be moderated by Lynne M. Schmelz-Keil, Rutgers University.

The Section will also sponsor a tour of the La Brea Tar Pits and the George Page Museum of Archaeology (June 29, 9:30 a.m.-12:00 p.m.). Registration is limited to 30 and the museum cost is $\$ 1.50$. Contact: David L. Perkins, Head Bibliography Librarian, California State University, Northridge, CA 91330.

Art Section: "New Trends in Art Publishing: The Los Angeles Area" (June 28, 2:00-4:00 p.m.) will feature representatives from art book and periodical publishing houses in the Los Angeles area who will discuss examples of their work. Modera- tor of the program will be Judith Hoffberg, editor of Umbrella: among the speakers are Linda Burnham, editor of High Performance; and a representative from the Women's Graphic Center, Los Angeler.

Asian and African Section: "Intellectual Freedom in Asia and Africa” (June 27, 9:30 a.m. - 12:30 p.m.), co-sponsored by AAS, the International Relations Round Table, and the SRRT International Human Rights Task Force, will feature Richard Baum, UCLA Department of Political Science; Hassan Shahbaz, editor of the Iranian periodical Rahavard; and Kyalo Mativo, editor-in-chief of Ufahamu, the journal of the African Activist Association.

Audio-Visual Commitee: “Cable Communications - Inter-ACTION: Information Delivery in the 1980s" (June 26, 2:00-5:30 p.m.), a program co-sponsored by the LITA Video and Cable Communications Section, will offer information on the rapidly developing technology of cable communications in the library setting. Topics will include library applications of cable communications, data transmission via cable, and interactive video. Scheduled speakers include George Beers, De Anza College: Kenneth Dowlin, Pikes Peak Regional Library District; Richard W. Boss, Information Systems Consultants: and Richard Adler, Institute for the Future.

Bibliographic Instruction Section: "The Research Process: Implications for Bibliographic Instruction" (June 26, 2:00-5:30 p.m.) is also sponsored by ACRL's Science and Technology' Section. The program will address the questions: How do scholars do research in subject disciplines? How are the literatures of disciplines generated, found, and used by researchers at all levels? What dolibrarians need to know about this process in order to aid research and teach others? Speakers will include David King, Houston Academy of Medicine; and Keith Russell, Council on Library Resources.

The BIS Postconference, "Bibliographic Instruction for the Non-Traditional Student" (June 29-July 1) will be held on the UCLA campus. Beginning Wednesday evening with a wine and cheese reception, the conference will provide an opportunity for viewing the award-winning film, "Gravity Is My Enemy." Peter Pomerantz, coordinator of library services for disabled users, University of California, Berkeley, will focus discussion on the specifics of library service to the handicapped. A panel discussion on Thursday afternoon will address the topic of bibliographic instruction for non-native English speakers and the culturally disadvantaged. Attendees will mark the close of the first day with a barbecue dinner at UCLA's Sunset 


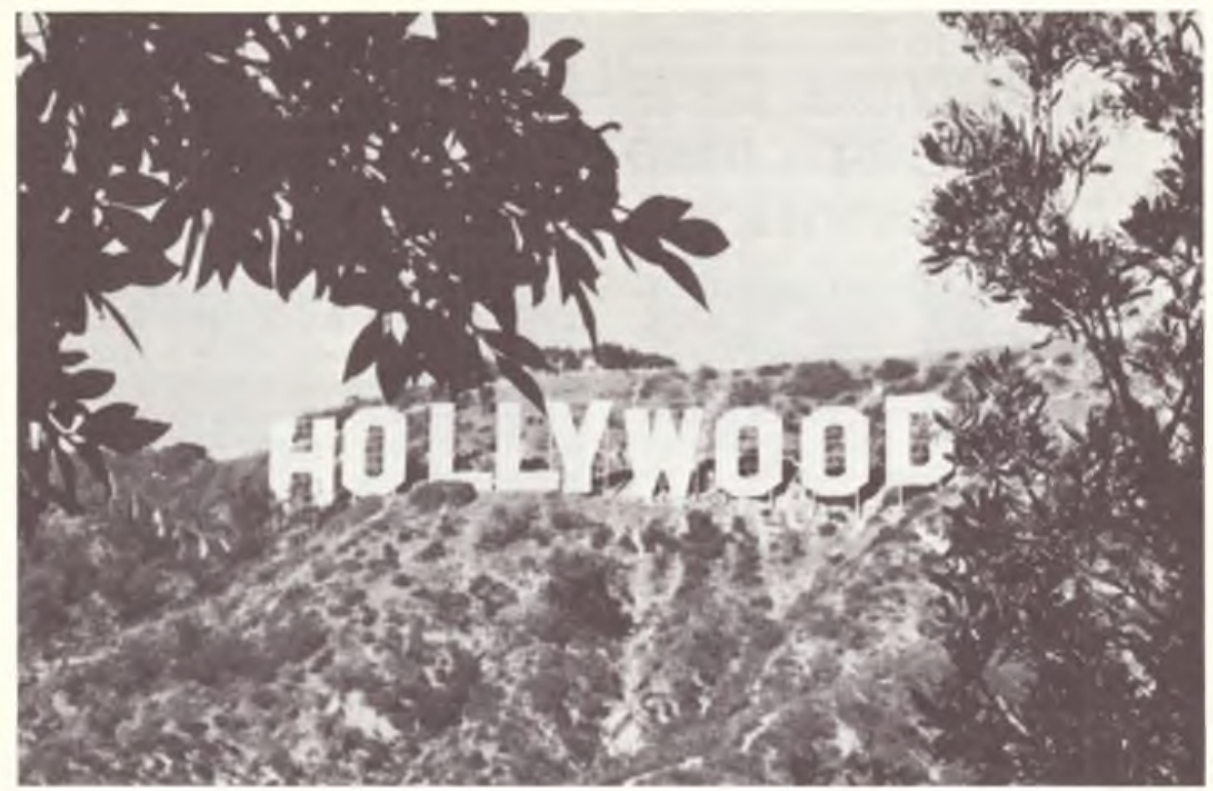

ACRL's Cinema Librarians Discussion Group will host a tour of three area film libraries at the ALA Annual Conference in Los Angeles.

Canyon Recreation Area. Discussion on Friday will center on unique aspects of service to the continuing education community. Sharon Rogers, associate dean for libraries and learning, Bowling Green State University, will then summarize the postconference. The registration fee of $\$ 105$ for ACRL members and $\$ 130$ for non-members includes all postconference materials, dormitory housing June 29 and June 30 , and meals from Thursday breakfast through Friday breakfast. Registration for those not staying in the dormitory is $\$ 70$ for ACRL members and $\$ 95$ for nonmembers. Deadline for registration is May 15 and is limited to 180. Contact: Mary Beth Bell, Community College of the Finger Lakes Library, Canandaigua, NY 14424

BIS Computer Concernis Committee: An open meeting (June 25, 9:30-11:00 a.m.), co-sponsored by the RASD Machine-Assisted Reference Section's Direct Patron Access to Computer-Based Reference Systems Committee, will present a discussion of issues relating to the patron and the computer from a public service viewpoint. Topics will include online end user searching of online catalogs, circulation systems, and bibliographic databases: computer-assisted instruction: and the impact of these processes on bibliographic instruction.

Cinema Librarians Discussion Group: "Film/TV Resources in Los Angeles" (June 28, 9:30 a.m. $-12: 30$ p.m., 2:00-4:00 p.m.) will consist of a morning panel discussion by seven theater and film librarians on local collections, and afternoon tours of the libraries of the Academy of Motion Picture Arts and Sciences, the Variety Arts Center, and the American Film Institute. A reception at the AFI will be held afterward. Tours are limited to 43 people and require an advance reservation. Cost: $\$ 10.50$. Contact: Monica Burdex, Reference Department, California State University Library, 18111 Nordhoff St., Northridge, CA 91324.

College Libraries Section: "Periodical Selection in College Libraries: Reports of Practitioners" (June 26, 9:30-11:00 a.m.) will be moderated by Pamela Snelson, Drew University. The speakers are as follows: Phyllis Kaiden, Union College, "From Periodicals Budget Cuts to Management Information Systems," will provide suggestions on using management information reports as collection development tools; Rosalee McReynolds, Loyola University, New Orleans, "Limiting Periodicals Collections in an Undergraduate Library," emphasizes deselection in undergraduate libraries; and Katherine Konopasek, St. Xavier College, " A Survey of Journal Use Within the Undergraduate Library at the University of Illinois at UrbanaChampaign," describes the library's method of evaluating periodical use.

Community and Junion College Libraries SECTION: The CJCLS program, "Community College Library Connections" (June 26, 12:30-6:00 p.m.), will focus on community college library interrelationships with instruction, copyright, other 
libraries, and community agencies. Speakers include Ivan Bender, Films Incorporated; Jo Ellen Flagg, Charleston (W.Va.) Public Library; Ruth Person, Catholic University of America; Hal Stone, Los Angeles City College; and Norman Tanis, California State University at Northridge. A business meeting and cocktail party follow the program. Tickets, including luncheon, are $\$ 16$ by advance registration no later than June 10 . Send check or money order payable to Joseph Lindenfeld to: Joseph Lindenfeld, 491 N. Highland St., Apt. 12, Memphis, TN 38122.

CJCLS will host a bus tour to two community college libraries: the Los Angeles Trade-Technical College and Santa Monica College. Tickets are $\$ 7$ by advance reservation no later than June 10 . Send check payable to Joseph Lindenfeld (address above).

Education and Behavioral Sciences Section: “'The Micros Are Coming: Models for Public Access" (June 27, 9:30 a.m.-12:30 p.m.) features Donald Piele, associate professor of mathematics at University of Wisconsin-Parkside, as keynote speaker. A panel consisting of Betty Cleaver, Ohio State University; Susan Lytle, Texas A\&M; and Linda Piele, University of Wisconsin-Parkside, will discuss public use of microcomputers in libraries.

English and A Merican Literature Discussion Group: "Bibliographic Instruction for English Department Courses" (June 28, 2:00-4:00 p.m.) will be addressed by Bill McPheron, SUNY-Buffalo, and Mary George, Princeton, with Maureen Pastine, San Jose State University, acting as moderator. A business meeting will follow the discussion.

Law and Political Science Section: "Online Database Searching in Law and Political Science" (June 27, 9:00-11:00 a.m.) will focus on techniques for searching PAIS International and USPSD. George Plosker, regional manager for the Los Angeles Region of DIALOG, will give the presentation.

Legislation Committee: "Buttonholing Your State Legislator: The Academic Library Connection" (June 25, 2:00-4:00 p.m.) will examine ways in which academic librarians can be active in bringing the concerns of higher education to state governments. Speakers include: Peter Goldschmidt, University of California System; Alfred D. Sumberg, associate general secretary, American Association of University Professors; and Ann Moreau, executive director, Indiana Library Association. A reactor panel discussion will follow the speakers.

Rare Books and Manuscripts Section: "Manuscripts and Archives/Rare Books and Other Printed Material: Integration or Separation" (June 28, 2:00-4:00 p.m.) examines the administration of $\mathrm{fa}-$ cilities containing both manuscripts and archives, and rare books and other printed materials. Clifton H. Jones, director of the DeGolyer Library, Southern Methodist University, will describe and evaluate the separate traditions, conventions, and patterns of training and experience, and peer group identification of archivists, manuscripts librarians, and librarians dealing with rare books and other printed materials. William Joyce, chief of the Rare Book and Manuscript Division, New York Public Library, will describe and evaluate the administration of manuscripts and archives integrated with rare materials. Richard C. Berner, head of the Archives and Manuscripts Division, University of Washington, will describe and evaluate the administration of manuscripts and archives separate from rare materials.

The RBMS Postconference, "The Enemies of Books Revisited: Rare Book Librarians and Their Public" (June 29-July 2), will be held on the UCLA campus. See C $b R L$ News, April 1983, p. 112, for details. Registration forms are available from ACRL/ALA, 50 E. Huron St., Chicago, IL 60611, and should be returned by May 15 .

Science and Technology Section; "Perspectives on Proceedings" (June 25, 9:00-11:00 a.m.) will examine the current state of conference proceedings publication and its bibliographic control in libraries. A panel discussion will feature a representative from a society which regularly produces proceedings of its meetings, a representative of a commercial publisher of proceedings, an indexing service representative, and a librarian.

Slavic and East European Section: "Archives and Libraries in Eastern Europe and the Soviet Union" (June 26, 2:00-4:00 p.m.), will inform librarians and specialists in the field of Slavic studies about major libraries and their activities in Eastern Europe.

Staff Development in Academic Libraries Discussion Group: Three one-hour meetings (June 26, 4:30-5:30 p.m., 8:00-10:00 p.m.; June 27, $11: 30$ a.m. $-12: 30$ p.m.) will take the form of an information and idea exchange on staff development programs and issues in academic and research libraries. There will be informal presentations by members on new activities within their libraries.

Undergraduate Librarians Discussion Group: Anne Mathews, associate professor of librarianship at the University of Denver, will lead a workshop (June 28, 2:00-4:00 p.m.) on communication approaches for use within an undergraduate library, including marketing techniques.

University Libraries Section: "Publishers and Academic Libraries: Economic Survival in the Eighties" (June 27, 9:00-11:00 a.m.) will help academic librarians understand the problems faced by publishers and help publishers appreciate the problems and constraints on library acquisitions caused by budget decreases and inflation. The program is 


\section{At Midwest Library Service, We Take The Team Approach To Assist Your Library}

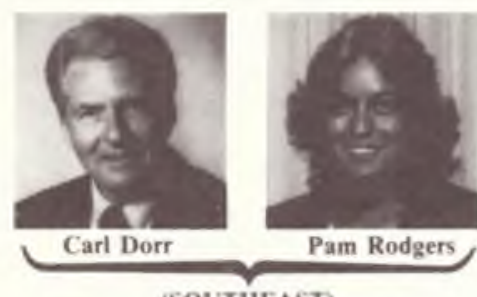

(SOUTHEAST)

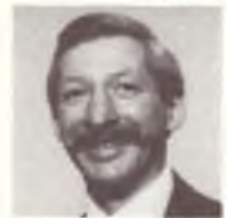

Kevin P. Coyle

Linda Market

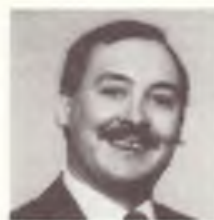

Forrest E. Link

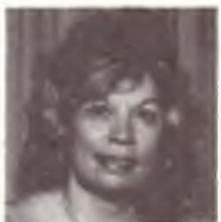

Carol Lehmkuhl

(NORTHEAST)

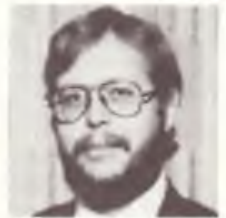

Kim S. Anderson (MOUNTAIN PLAINS)

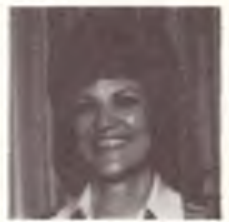

(MIDWEST)

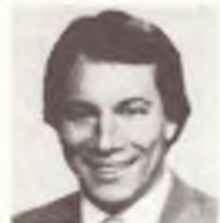

Lawrence D. Nagel

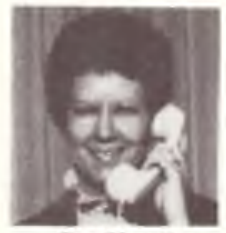

Pat Hamil

(WEST)

To best serve your needs, we have formed five problem-solving service teams to help take the hassle out of book-buying. Each team is composed of a Sales Representative in the field and a Customer Service Representative in our home office.

Once alerted by your phone call made on our Toll-Free WATS Line, 1-800-325-8833, (Missouri customers, please call COLLECT 0-314-739-3100) your problem-solving team, geographically assigned to your library, goes into

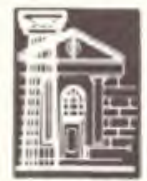

MidwesI Library Service 11443 S1. Charles Rock Road Bridgeton, Mo, 63044 action immediasely.

It is another facet of Midwest Library Service's tradition of excellence.

May we have the privilege of serving your library?

\section{'23 Years of Service To College} and University Libraries' 
co-sponsored by the ALA Resources and Technical Services Division/Association of American Publishers Joint Committee. Speakers include Richard M. Dougherty, director of libraries, the University of Michigan; Robert J.R. Follett, chairman, Follett Corporation, Chicago; and Jack Miles, editor, University of California Press.

Western European Specialists Section: "France and Francophone Canada: Publishing Trends, Selection Tools, and Library Collections Today" (June 27, 9:30 a.m.-12:30 p.m.) will bring together librarians involved in and knowledgeable about selecting French language materials and a representative of the French Publishers' Association. The speakers include: Charles Fineman, University of California, Santa Cruz, on collecting French materials; Jean-Pierre Bardos, Syndicat National de l'Edition, on publishing in France in the 1980s; Assunta Pisani, Harvard, on selection of French materials; Richard Gardner, UCLA Library School, on French language publishing in Canada; and Joan Higbee, on the evaluation of French language collections.

\section{OTHER PROGRAMS OF INTEREST}

- The Audiovisual Committee of the Resources and Technical Services Division will present "The Movies: Organization of Film Libraries and Libraries About Film" (June 25, 9:30-11:00 a.m.), a program cosponsored by ACRL's Audiovisual Committee. The lecturers will provide information on the organization and scope of the libraries of the UCLA Film Archives, the California Institute of the Arts, the Academy of Motion Picture Arts and Sciences, and MGM.

-The Comparative Library Organization Committee of the Library Administration and Management Association's Library Organization and Management Section will offer a program (June 28, 9:00-11:00 a.m.) on "Hierarchy, Matrix, Theory $\mathrm{Z}$ and Beyond: How Should a Library Be Organized in the 1980s?" that is cosponsored by ACRL's University Libraries Section. Four speakers will consider the organization of libraries during the next two decades with emphasis on the impact of technology, networking, and decreased resources.

- The Library History Round Table (June 27, 2:00-4:00 p.m.) will present a program entitled, "So Good and Worthy a Designe," that focuses on library public services in late 17 th and 18 th century London and Philadelphia. Peter Hoare, university librarian at the University of Nottingham, will discuss Archbishop Tennison's Library and public library provision in England, 1660-1715. Marie Korey, head of the Rare Book Department at the Free Library of Philadelphia, will examine readers and libraries in 18th century Philadelphia.

- The Library Service to the Deaf Section of the Association of Specialized and Cooperative $\mathrm{Li}$ brary Agencies will present "Serving Deaf Students in Academic Libraries" (June 25, 9:30 a.m.-12:30 p.m.). The program, co-sponsored by the ACRL Community and Junior College Libraries Section, will include a presentation by Herb Larson of California State University, Northridge, on deaf students on campus; the showing of two videotapes, by Austin Community College and Gallaudet College, on communicating with deaf students; and a five-member panel discussion by academic librari- ans who provide library orientation and bibliographic instruction to deaf students.

- The Map and Geography Round Table and the ACRL Rare Books and Manuscripts Section will offer Part II of "Mapping the Trans-Mississippi West" (June 26, 2:00-4:00 p.m.), a theme first developed at ALA Annual Conference in San Francisco. Speakers include James Coombs (Southwest Missouri State University), Norman J. W. Thrower (UCLA), and John B. Garver, Jr. (National Geographic Society).

-The Planning and Evaluation of Library Services Committee of the Library Administration and Management Association's Library Organization and Management Section will offer "Skills for Library Planning: A Practical Sequel" (June 28, 2:00-5:30 p.m.) as a sequel to its program at ALA Annual Conference in Philadelphia. Directed toward all levels of library managerial staff and appropriate for all type-of-library settings, the program will afford a practical demonstration of the relation between specific skills and planning activities. Session leaders are Dorothy J. Anderson, UCLA; Joseph Rosenthal, UC-Berkeley; and Douglas Zweitzig, University of Wisconsin. Participation is limited to 300 people preregistered in two out of three group sessions. Contact: Meredith Butler, University Library, Room 109, SUNY, Albany, NY 12222, before June 1.

- The Resources and Technical Services Division's Cataloging and Classification Section will host a bibliographic institute, "Blood, Toil, Tears, and Sweat: Rules and Formats" (June 28, 8:00 a.m.-1:00 p.m.), as part of the ALA/RTSDsponsored video teleconference that will be transmitted via the services of the Public Service Satellite Consortium to 114 receive sites across the continent. Topics and speakers include: "AACR 2 and ISBDs," Peter Lewis (British Library) and Lucia J. Rather (Library of Congress); "MARC Formats," Henriette D. Avram (Library of Congress) and Allen Veaner (University of California, Santa Barbara); "Filing Rules," Nancy R. John (University of Illinois at Chicago) and Joseph Rosenthal (University of California, Berkeley). D. Kaye Gapen (University of Alabama) will summarize the proceedings. 


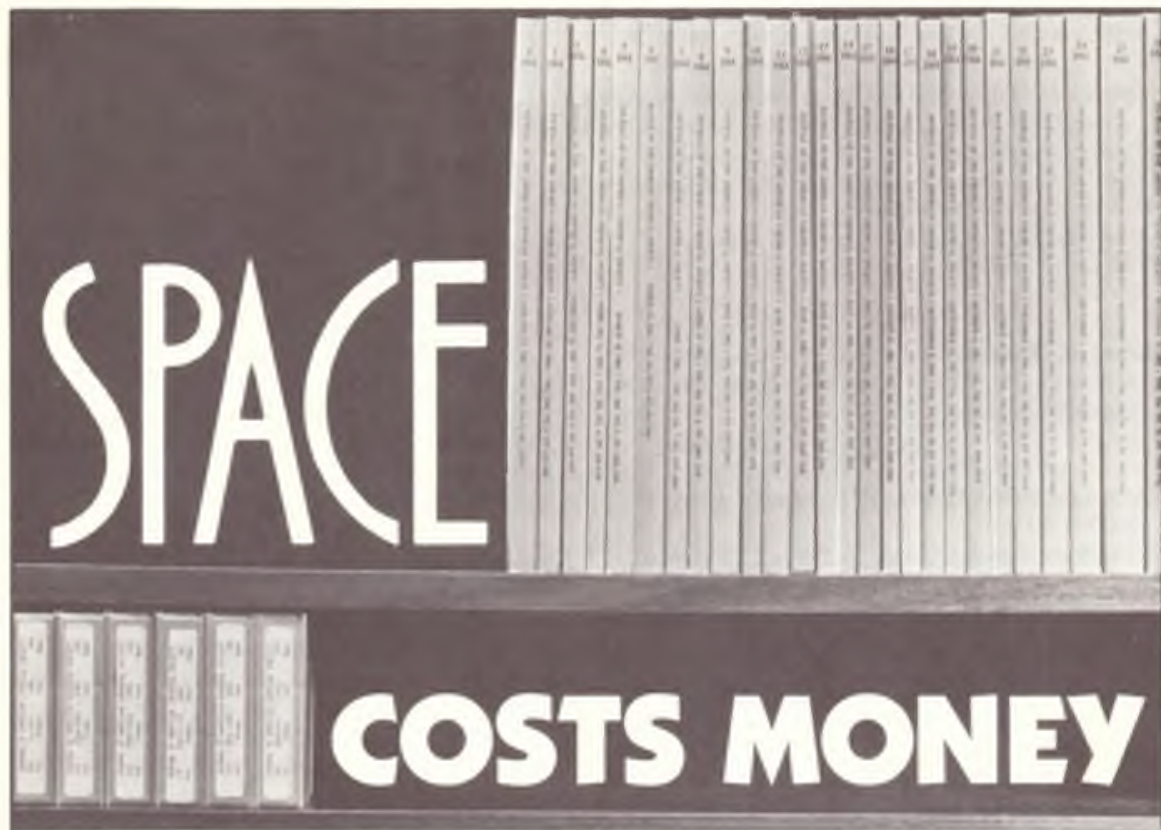

When you manage a library these days, you're well aware that space is precious. And additional shelves for backfile volumes are expensive.

Well, the American Chemical Society knows your concerns. That's why all the Society's 20 primary publications in the field of chemistry are available in microfilm editions - including complete volumes back to 1879 .

\section{Start Saving Space In Your Chemical Reference Files Now!}

If you are setting up a microfilm system, expanding or changing one, or just want to discuss the possibilities-an ACS Sales Representative is ready to work with you. Just fill in the coupon below, or better yet, call us:

\section{American Chemical Society}

Our 15th Year in Micropublishing

\section{ACS Microfilm Editions-Information Coupon}

Yes, please send me more

information on American

Chemical Society publications

as indicated below:

$\square$ ACS Microforms Catalog

ACS Books \& Journals

Catalog (includes

microforms information)
Name

Organization

Address

City, State, Zip

Country

Telephone (

Return this coupon to: American Chemical Society, Sales Office, 1155 16th Street, N.W., Washington, D.C. 20036 